\title{
A Study on Water Demand Load Estimation by Using Unit of Living Water - Focused on Micro Water Supply Area in Daegu City
}

\author{
Ji-Soo Lee, Won-Hwa Hong* \\ Departmentof Architecture, Kyunpook National University,Daegu, Republic of Korea. \\ Email: *iris9972@naver.com
}

Received 2013

\begin{abstract}
Water supply capability has been significantly reduced as water demand has been increased due to changes of the world's weather, causing the increase of drought frequency, and urbanization. In terms of water production, water can be secured by construction a dam or procuring substitute water. However, the study approaches in terms of management of water supply area to control the existing water efficiently. Therefore, water demand was estimated by buildings, by which water load of micro water supply area was calculated. As a result, the deviation of water demand for 1,357 micro water supply areas could be calculated while the alternatives to dissolve the spatial demand unbalance were suggested by two types. From the study, firstly, we could anticipate the total water supply demand from the total sum by filtration plants but it was not possible to anticipate the characteristics of distribution within urban areas. For this, the study attempted to anticipate the demand of each 250 thousands of buildings, comprehending the demand of micro areas. Secondly, based on the built results, we suggest the directions to dissolve the water demand unbalance between and among regions, which could be the foundation to suggest the concrete methodology in the future.
\end{abstract}

Keywords: Water Supply Area; Water Demand Estimation; Basic Unit, Water for Living; Smart Water Grid

\section{Introduction}

Due to the rapid industrialization, many cities have been larger and the recent weather changes cause the severe drought. Therefore, the water demand increases about 6 times in 20th century while the water supply has been unstabilized; it is expected that in 2025, about two thirds of the world population encounter short supply of water. In addition, the water dispute is getting severe between regions, and it was found that totally 58 cases of disputes occurred from the cases of each administration and 5 rivers' areas of Korea for 10 years(SWRRC 2008). Such problems show that the water procurement by dams had to be limited. As an alternative, smart water grid is suggested by utilizing the latest IT technology in terms of water demand control. The core of smart water grid is to dissolve spatial and temporal unbalance through efficient water control. However, to currently construct the smart grid system in the territory, it is prerequisite to estimate the water demand for a micro size, which is 5 thousands of households or micro water area. The domestic micro size water supply areas are sub-divided into water supply

${ }^{*}$ Corresponding author. zones of the filtration plant, so the water usage can be calculated but it is not possible to anticipate the water usage by buildings owing to the classification of building use and the properties.

Therefore, the study realizes the primary purpose of anticipating water usage by buildings in an urban area by using the basic unit of city water . Then, based on the calculated data, the water load of sub-divisions within an urban area is also calculated. The study would contribute to establishing the methodology of dissolving the unbalanced water supply in subdivisions and be the fundamental data to construct the smart water grid.

\section{Setting a Unit of Living Water by Building Use Type}

Water can be roughly divided into Living water and agricultural water. Living water is also sub-divided into living water and industrial water; the former(living water) is, in turn, divided into household water and city utilization water(Water membarane, 2006). The study limited the subject to the living water, which occupies about 84\% (Daegu Statistical Annual Report, 2011) of Daegu city water. Before applying the basic unit, it is necessary, 
in case of domestic household water, to convert the basic unit per person to the basic unit of area. Meanwhile, the city utilization water is applied with the existing basic unit numbers and applications..

\subsection{Setting a Unit of House Hold Water}

Household water consists of toilet water, washing water, bath water and laundry water by applications. The basic unit of the study is the basic unit by house types, which was suggested by Kim. According to the above study, the house type(Detached house[141 lpcd], Apartment [155l pcd], Multi unit dwelling[159 lpcd]) and the basic unit were applied. The procedure and method to convert the basic unit per person to the basic unit per area in the study are as follows.

- The average gross floor area was calculated by using the no. of household(statistics) while the gross floor area by types was calculated by using the building spatial data of Daegu.

- Meanwhile, the basic unit by types and the average residence per house were used to estimate the water usage per house.
- Then, the spatial information was used to estimate the total floor area of a specific building while the water usage was estimated by using the average total floor area per house and the water usage per house by types, which were estimated in the above procedure.

That can be summarized as follows.

$$
Q_{t}=\frac{A_{s} / U_{r} \times P_{D . a}}{A_{D . t} / H_{D}}
$$

$\left(\mathrm{Q}_{t}\right.$ : Water consumption of target building [ $\ell /$ building-day]; $\mathrm{A}_{\mathrm{s}}$ : Gross aera of Target building $\left[\mathrm{m}^{2}\right]$; $\mathrm{U}_{\mathrm{r}}$ : Water consumption units by house type [ $\ell /$ capita.day]; $P_{D . a}$ : The average number of people per household (Daegu city); $A_{D . t}$ : Total gross area of residential buildings (Daegu city) $\left[\mathrm{m}^{2}\right] ; H_{D}$ : The number of household(Daegu city)

\subsection{Setting a Unit of City Utilization Water}

The basic unit to apply city utilization water was applied by the business types and the basic units suggested by Lee. The following table shows the business type, based on the Korea Standard Industrial Classification and represents the basic unit by business types.

Table 1. Unit of city utilization water.

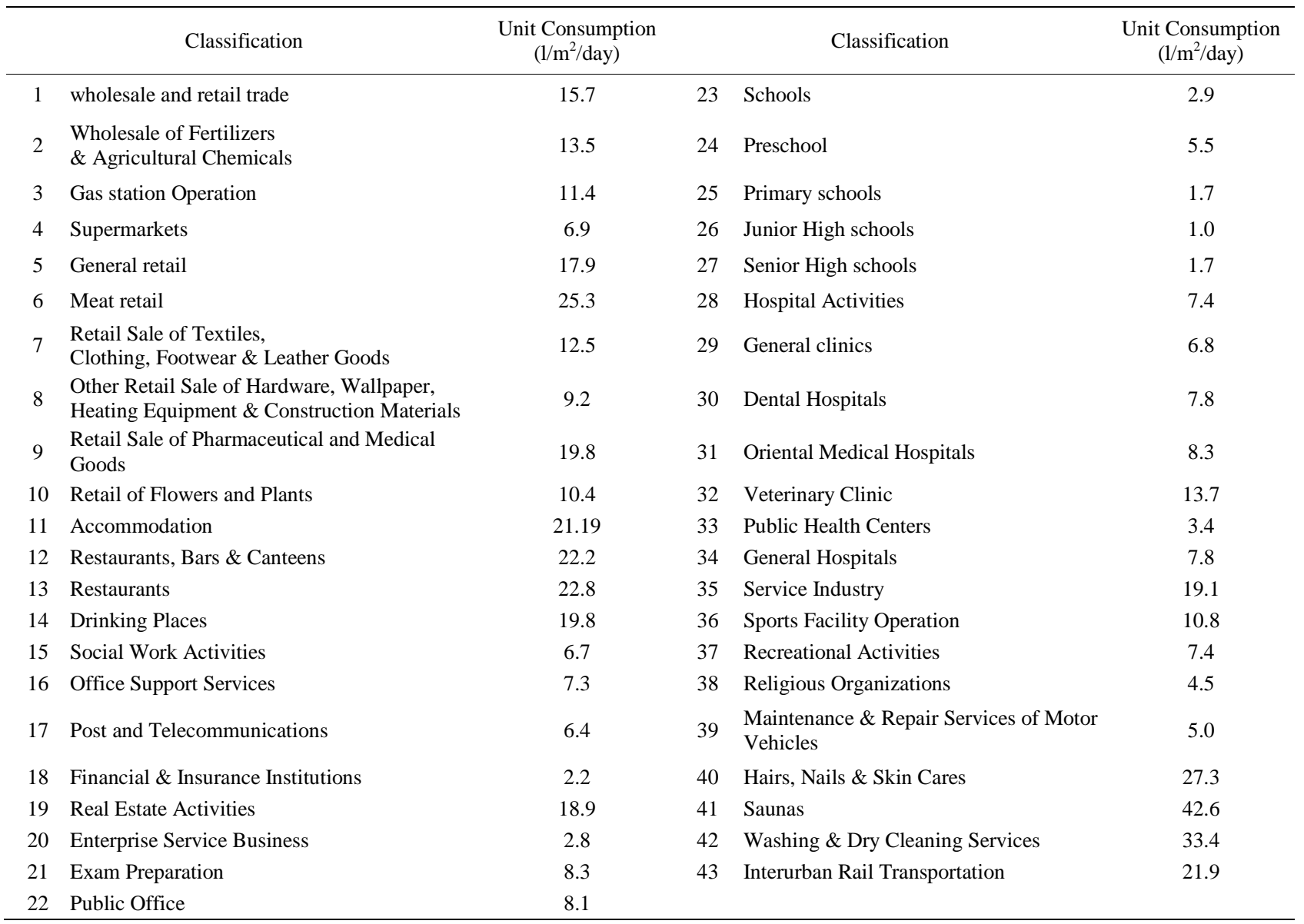




\section{Building a Data of Water Demand in Daegu City}

\subsection{Status of Water Supply System in Daegu City}

Daegu, the subject city of the study, accommodates 2,529 thousands of population in $883.7 \mathrm{~km}$ of total area and 940 thousands of households. Administratively, the city consists of 8 gu and 139 dong. In the urban area, there are 5 filtration plants for living water and 1 filtration plant for industrial water. The total capacity of the facility is 1,640 thousands $\mathrm{m}^{3}$ daily, among which about $12 \%$, 200 thousands $\mathrm{m}^{3}$ of water is produced in Gong- san plant. The scope of the study, Daegu living water plant and production can be summarized as the Table 2 below.

As seen in the above, Mae-gok plant accupies about
$57 \%$ of the total living water production capacity, followed by Mun-san, Go-san, Ga-chang and Gong-san. Looking at the production rates to facility capacity of individual plants, it was about $51 \%$ on average but the production rate to the total facility capacity was just about 53\%.

\subsection{Building a Foundation Database for Calculating of Living Water Demand}

To estimate the living water usage of all buildings in Daegu, the fundamental data can be divided to 3 types.

1) Buildings' spatial data classified by residence types and business types of Daegu

2) Properties data to estimate household water and city utilization water(basic unit and gross floor area)

3) Diagram data of Daegu's small water supply areas

Table 2. Status of living water supply in Daegu city.

\begin{tabular}{|c|c|c|c|c|c|c|}
\hline \multirow{2}{*}{ Division } & \multirow{2}{*}{ Total } & \multicolumn{5}{|c|}{ Water for living } \\
\hline & & Mae-gok & Mubn-san & Go-san & Ga-chang & Gong-san \\
\hline $\begin{array}{l}\text { Capacities of Facilities } \\
\text { (thousand } \mathrm{m}^{3} / \text { day) }\end{array}$ & 1,440 & 800 & 200 & 350 & 50 & 40 \\
\hline Production mount & 769 & 441 & 187 & 96 & 30 & 15 \\
\hline $\begin{array}{l}\text { Household number of } \\
\text { Watersupply(thousand) }\end{array}$ & 892 & 490 & 242 & 85 & 42 & 33 \\
\hline $\begin{array}{l}\text { People number of water } \\
\text { supply (thousand) }\end{array}$ & 2,506 & 1,345 & 684 & 268 & 115 & 94 \\
\hline Water supply area & $\begin{array}{c}\text { 7(gu), 1(gun), 134(dong), } \\
\text { 3(eup), 6(myun) }\end{array}$ & $\begin{array}{c}\text { 4(gu),1(gun), 54(dong), } \\
\text { 3(eup), 5(myun) }\end{array}$ & $\begin{array}{c}\text { 3(gu), } \\
\text { 36(dong) }\end{array}$ & $\begin{array}{l}1 \text { (gu), } \\
1 \text { (gun) }\end{array}$ & $\begin{array}{c}\text { 1(gu), 1(gun), } \\
\text { 1(myun) 6(dong) }\end{array}$ & $\begin{array}{l}\text { 1(gu), } \\
\text { 7(dong) }\end{array}$ \\
\hline
\end{tabular}

Table 3. Classifications of building uses.

\begin{tabular}{|c|c|c|c|c|c|}
\hline \multirow{2}{*}{\multicolumn{2}{|c|}{ Classification }} & \multicolumn{2}{|c|}{ Numbers } & \multicolumn{2}{|c|}{ Gross Area } \\
\hline & & $\mathrm{n}$ & $\%$ & $\mathrm{~m}^{2}$ & $\%$ \\
\hline \multirow{4}{*}{$\begin{array}{l}\text { Residential } \\
\text { building }\end{array}$} & Detached house & 171,386 & 91.84 & 29,583,612 & 31.60 \\
\hline & Apartment house & 6,531 & 3.50 & $58,905,510$ & 62.93 \\
\hline & Multi-unit dwelling & 8,702 & 4.66 & $5,116,537$ & 5.47 \\
\hline & total & 186,619 & 100.00 & $93,605,659$ & 100.00 \\
\hline \multirow{9}{*}{$\begin{array}{l}\text { None Residential } \\
\text { building }\end{array}$} & 1 & 111 & 0.16 & 116,522 & 0.30 \\
\hline & 2 & 127 & 0.19 & 59,607 & 0.15 \\
\hline & 3 & 793 & 1.17 & 229,939 & 0.59 \\
\hline & 4 & 406 & 0.60 & 635,782 & 1.64 \\
\hline & 5 & 27,447 & 40.53 & $8,996,840$ & 23.25 \\
\hline & 6 & 3 & 0.00 & 23,710 & 0.06 \\
\hline & 7 & 4 & 0.01 & 1,891 & 0.00 \\
\hline & 8 & 1,085 & 1.60 & 278,908 & 0.72 \\
\hline & 9 & 38 & 0.06 & 13,475 & 0.03 \\
\hline
\end{tabular}




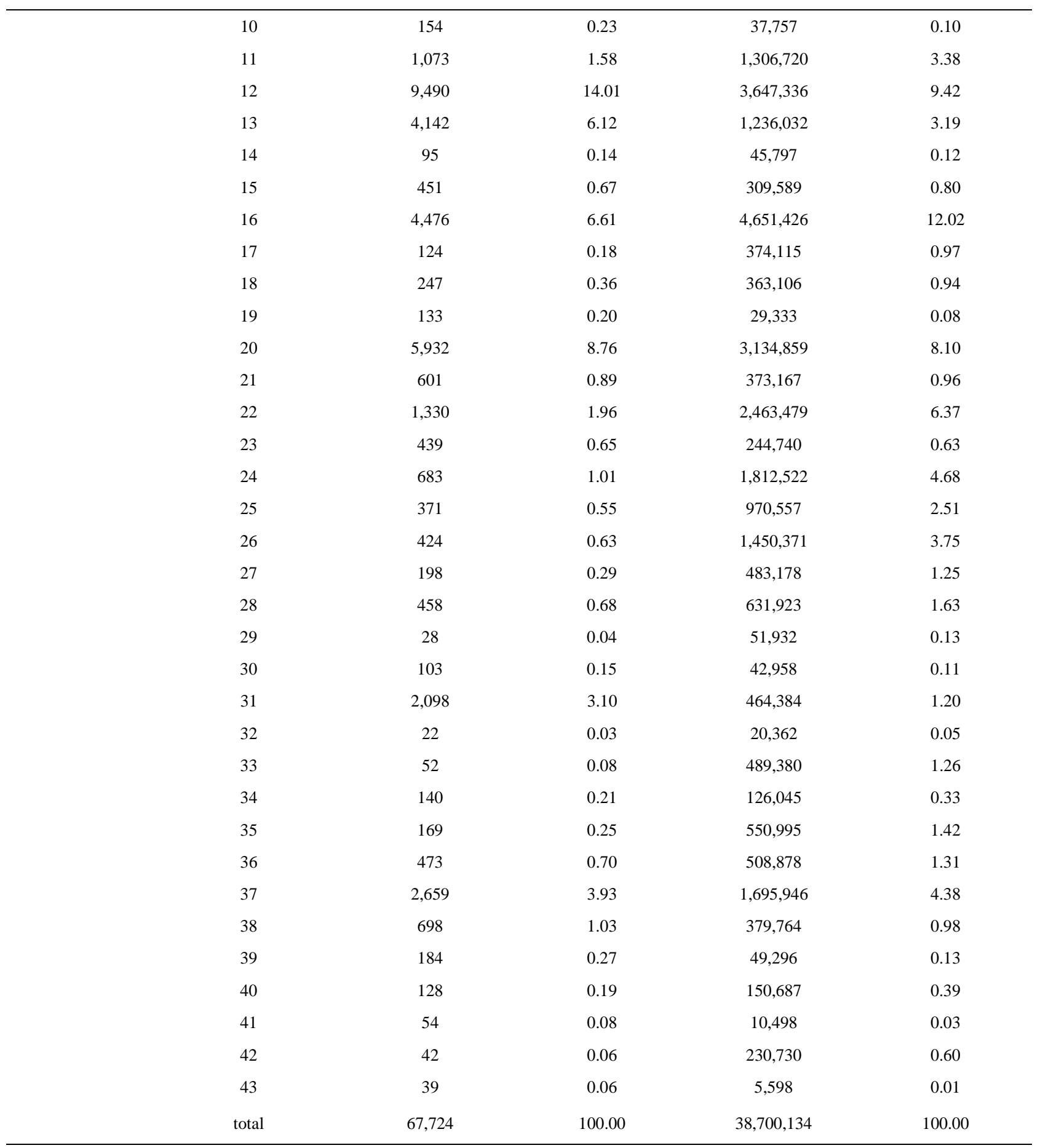

For the programs to integrate the above data and create the fundamental data, Arc GIS 9.3 was used. The spatial data created in the data is shp file format, so the attribute data is exported as the format of dbf file. To construct the data of 1), the usage of every building in Daegu except for factories from Daegu buildings' spatial data was classified. The data contain 0.25 million of data and they are divided into 3 residence types and 43 business types. The following figure shows the mapped classification data.

Then, to construct the data of 2), it should be constructed by dividing into household water and city utilization water. Firstly, to estimate the household water usage, the demand by each building was calculated by substituting 2.2 formula. The data regularly entered in the formula (1), besides the gross floor area of a specific building are as follows. 


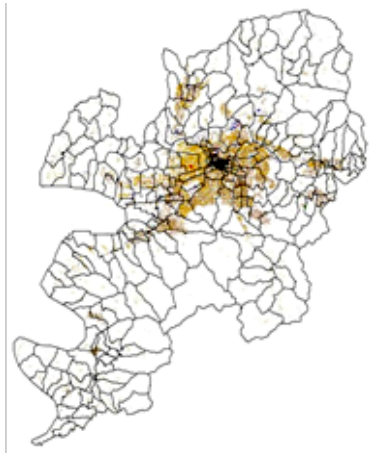

(a)

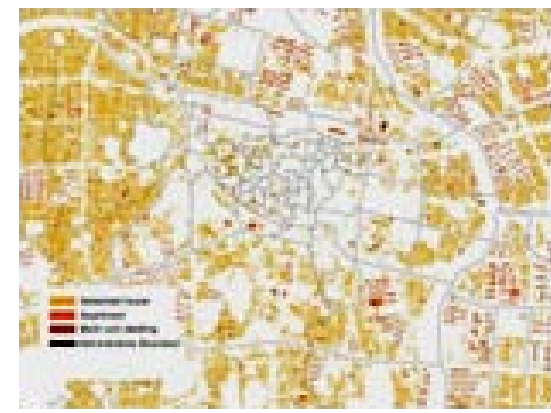

(b)

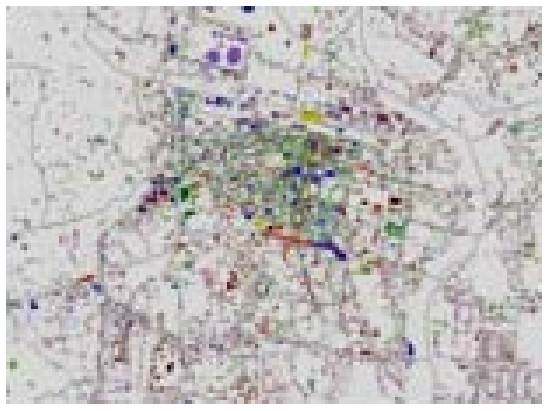

(c)

Figure 1. Classification of building uses in Daegu city. (a) Distribution of building uses in Daegu city; (b) Residential type classification in downtown; (c) Non-residential type classification in downtown.

Table 4. Data for estimation of household water demand.

\begin{tabular}{cccc}
\hline & $\begin{array}{c}\text { Detached } \\
\text { house }\end{array}$ & Apartment house & $\begin{array}{c}\text { Multi-unit } \\
\text { dwelling }\end{array}$ \\
\hline Ur $(\ell)$ & 141 & 159 & 155 \\
PD.a(p) & & 2.9 & \\
AD.t $\left(\mathrm{m}^{2}\right)$ & $29,583,612$ & $58,905,510$ & $5,116,537$ \\
HD $(\mathrm{N})$ & 361,447 & 464,960 & 60,435 \\
\hline
\end{tabular}

The data of 3) were converted to shp file format by using the data of Daegu City Water. The micro water supply areas of Daegu was sub-divided into 1,545 zones while the average area was about 240 thousands $\mathrm{m}^{2} .2,554$ buildings were contained into one zone to the maximum while 184 buildings on average are located within one zone. The above can be constructed to shp file as follows.

\section{Analysis of Water Demand Load in Daegu City's Micro Water Supply are}

\subsection{Water Demand Forecasting Within the Unit Building of the City}

The spatial distribution of water demand of Daegu was anticipated by using Arc GIS, based on 1) Building spatial data containing Residence types and business types of Daegu and 2) Attributes data(basic unit and gross floor area) to estimate the household water and city utilization water, which was constructed in 3.2.

The figure below shows the spatial distribution of the demands of household water, city utilization water and living water by building units of Daegu.

The table below shows the administrative spatial distribution of water demand while the comparison of the estimated living water demand of Daegu and the actual production was about $8 \%$ consistence. Looking at the results, Daeseo-gu occupied about 30\% of the total demand for household water while Suseong-gu occupies about $20 \%$ for city utilization water, which was about $20 \%$, the highest prediction.

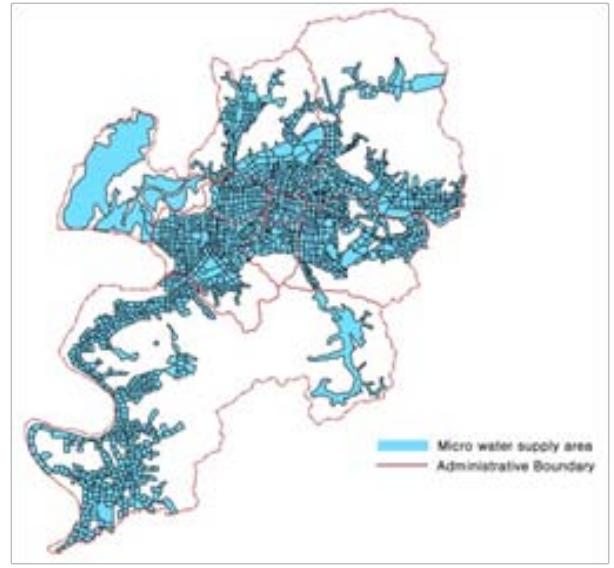

Figure 2. Constructed micro water supply area in Daegu city (shp file).

\subsection{Building an Water Demand Data on Micro Water Supply Area}

It was calculated by integrating the water demand by buildings and the spatial data of micro water supply areas, which were anlyzed in the above, and integrating the water usage by micro areas. To estimate them, the water demand data by buildings were converted to point data, which is, in turn, joined, based on micro areas' diagram data and location data.

As a result of integrating the building information of totally 1,545 micro areas and excepting other micro areas with no buildings, there were 1,357 areas. The figure shows the results of classifying the estimated demand by using natural break classification

As a result, the average demand of micro water supply areas was about $5,424 \mathrm{~m}^{3}$ and the difference between the max. and average was about 2,432,177 $\mathrm{m}^{3}$. In addition, standard deviation was $163,700 \mathrm{~m}^{3}$, indicating that there are severe unbalance between and among micro areas and that the areas should be readjusted, based on the demand. 


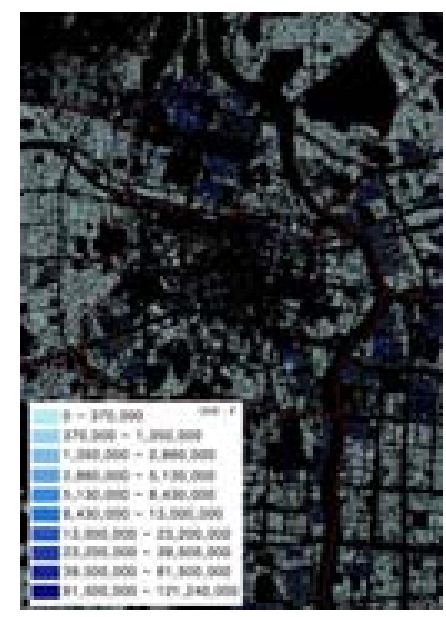

(a)

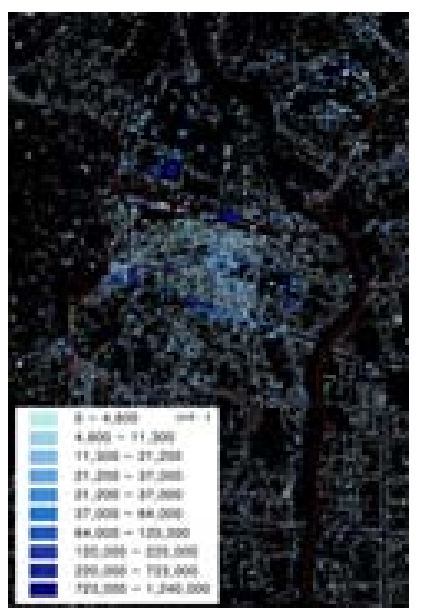

(b)

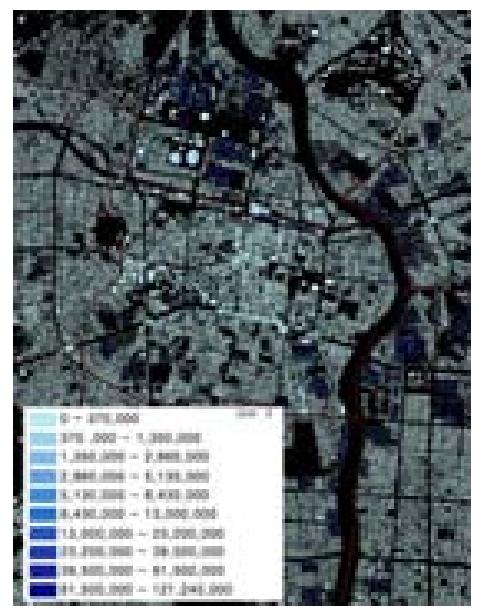

(c)

Figure 3. Estimation of living water demand by buildings. (a) Residential water; (b) City utilization water; (c) Living water.

Table 4. Estimation of water dimand by administrative area.

\begin{tabular}{lccc}
\hline \multirow{2}{*}{ Administrative area } & \multicolumn{3}{c}{ Living Water consumption( $\ell$ /day) } \\
\cline { 2 - 4 } Jung-gu & Household water(a) & Urban water(b) & Total(a+b) \\
Dong-gu & $2,268,025,115.9$ & $62,353,597.0$ & $2,330,378,713.0$ \\
Seo-gu & $7,243,507,305.6$ & $69,132,776.6$ & $7,312,640,082.2$ \\
Nam-gu & $2,526,147,690.6$ & $12,263,841.0$ & $2,538,411,531.6$ \\
Buk-gu & $1,842,759,505.5$ & $42,627,634.7$ & $1,885,387,140.2$ \\
Suseong-Gu & $14,463,961,482.2$ & $75,380,174.8$ & $14,539,341,657.0$ \\
Dalseo-gu & $20,064,332,667.4$ & $87,349,282.6$ & $20,151,681,950.0$ \\
Dalseong-gun & $21,733,972,247.3$ & $52,708,298.9$ & $21,786,680,546.2$ \\
Total & $3,042,867,072.1$ & $30,878,524.3$ & $3,073,745,596.5$ \\
\hline
\end{tabular}

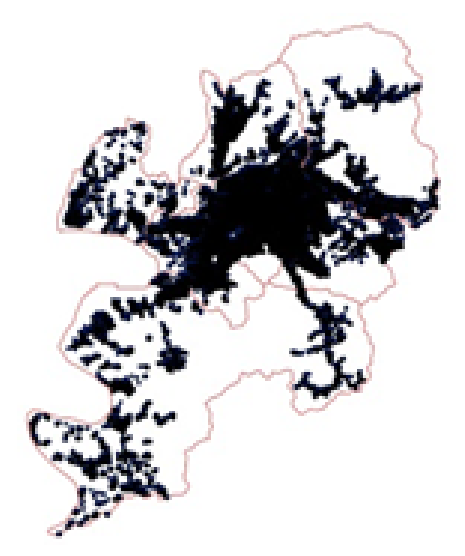

(a)

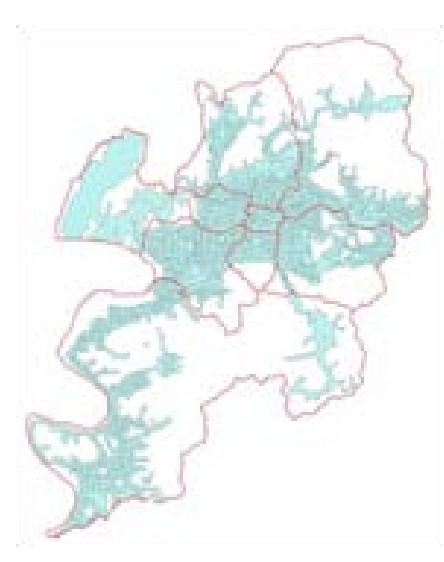

(b)

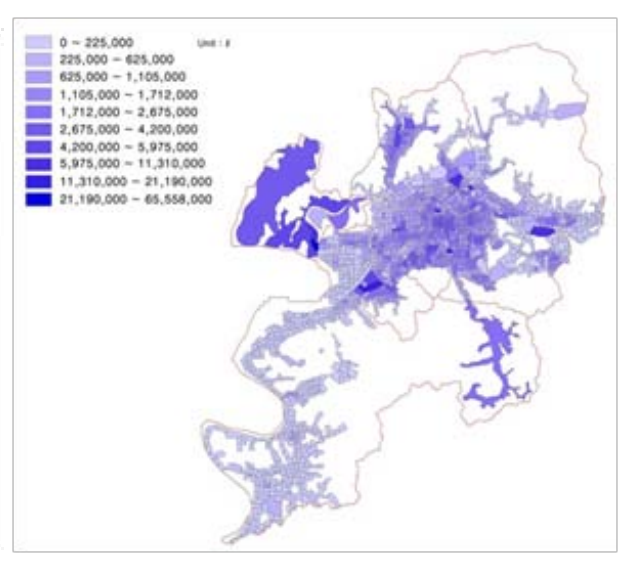

(c)

Figure 4. Estimations of water demand be micro water supply area using overay analysis. (a) Building data(point); (b) Micro water supply area(polygon); (c) Distribution of water demand by Micro water supply area. 


\subsection{Adjustment Measures of Water Demand Load on Micro Water Supply Area}

As analyzed above, since there is much deviation of water demand, alternatives to reduce the unbalance should be studied. For this, the study extracted top $10 \%$ of the 1,357 micro areas, 135 areas were extracted, establishing the problems and suggesting the method to re-adjust the areas.

The estimated water demand for the $10 \%$ areas occupies about $76 \%$ of the estimated total water demand, $55,786,386 \mathrm{~m}^{3}$. In addition, looking at density analysis (gross floor areap $\left[\mathrm{m}^{2}\right] /$ micro area $\left[\mathrm{m}^{2}\right]$ ) results (figure), it was 1.71, 1.17 higher than the average of Daegu, 0.54. In addition, the average area of micro areas was $368,000 \mathrm{~m}^{2}$, which is $12,000 \mathrm{~m}^{2}$ larger than the average area.

Meanwhile, considering the frequency of buildings, it was analyzed that 184 buildings are located on average for the total micro areas while 531 buildings were contained in top $10 \%$ areas.

Based on the above results, two types of alternatives can be suggested to reduce the deviation of loads between and among areas. Firstly, an area where the building density is high but spatial area is broad, so more buildings are contained would be divided. The figure below shows the representative area for the first type. The area's density was 0.087 , which is just the lowest $40 \%$ of the total areas but the no. of buildings was 1,504 , which is top $0.4 \%$. To divide an area.

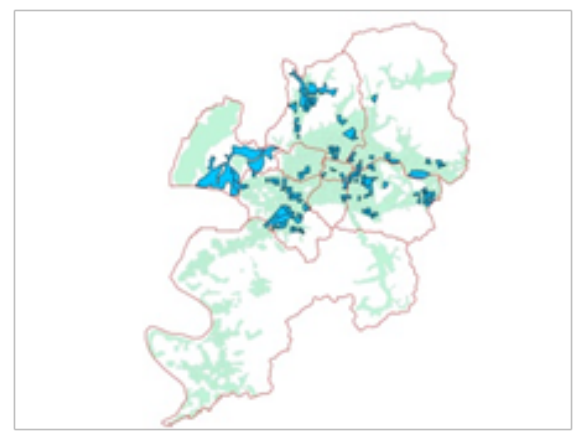

Figure 5. Top $10 \%$ of water demand area.

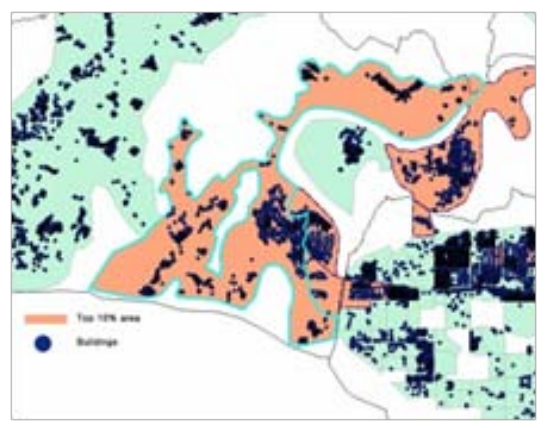

Figure 6. Result of density analysis.
The second type is an alternative re-adjusting the high density area, which is frequently found in urban areas (Figure 8). In the area of the figure below, interchange/ adjustment alternative of cross-areas to neighboring areas can be suggested while the interchange unit is desirably block, in consideration of structure of water pipes.

\section{Conclusion}

The study suggest the alternative to dissolve the water supply unbalance by regions, the core subject of smart grid and to reduce the deviation. For this, while analyzing the load by micro water supply areas, the water demand of all buildings except factories in Daegu was estimated while the spatial distribution of the demand can be comprehended. As a result of the study, the place estimated to have the largest demand of living water was Dalseo-gu, in which household water usage was especially high. After analyzing the estimated water demand and the existing water supply areas, the standard deviation of 1,357 areas was $163,700 \mathrm{~m}^{3}$, suggesting that the unbalanced state should be dissolved by an alternative. However, the alternative suggested in the study is a kind of directions, so more effort is required to substantialize it. Although the study suggests the types based on the frequency of buildings and the density, the further study

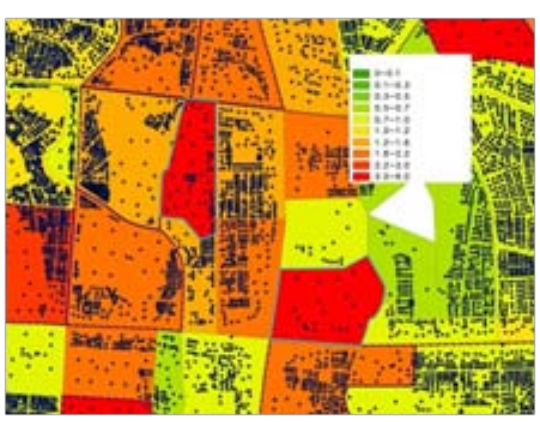

Figure $7.1^{\text {st }}$ re-adjustingalternative.

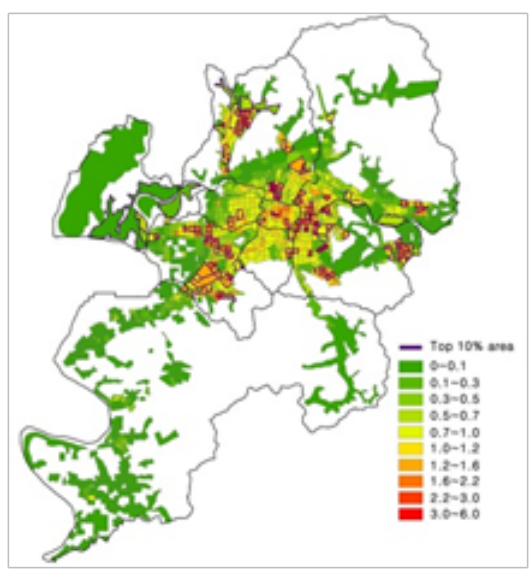

Figure 8. 2nd re-adjusting alternative. 
would suggest the methodology, based on the basic unit of usages within the areas.

While it was possible according to the previous studies to comprehend the total water demand from the total production of filtration plants, it was not possible to comprehend the small water demand of micro water supply areas due to the difference of authorities. The study was meaningful that it provides the fundamental data to construct the smart water grid by enabling the water demand by micro areas and estimation of water demand by buildings while it is expected that the study would contribute to the efficient control of water, which is the important issue for the countries.

\section{Acknowledgements}

This work was supported by the National Research Foundation of Korea(NRF) grant funded by the Korea government(MEST) (No. 2012-0008716).

\section{REFERENCES}

[1] Waterworks Headquarters Daegu Metropolitan City, “Waterworks Emergency Management Manual,” 2011.

[2] Ministry of Environment, "Manual of water supplydemandforecasting work,"2008.

[3] Lee. Doojin, Kim. Juwhan and Kim. Hwasoo, "Statistical Analysis on Non-Household Unit Water Use for Business Categories,” Journal of Civil Engineering, Vol. 29, No. 4, 2009, pp. 385-396.

[4] Kim. Hwasoo, Lee. Doojin, Kim. Juwhan, and Jung. Kwansoo, "End-use Analysis of Household Water by Metering," Journal of Civil Engineering, Vol. 28, No. 5, 2008, pp. 1-7.

[5] Yoo. Seunghoon, Jung. Kunoh and Yang. Changyoung, "Analysis on the Municipal Water Demand in Seoul Using the Micronomic Household Data," The Seoul Institute, Vol. 6, No.1, 2005 